University of Nebraska - Lincoln

DigitalCommons@University of Nebraska - Lincoln

Publications from USDA-ARS / UNL Faculty

U.S. Department of Agriculture: Agricultural

Research Service, Lincoln, Nebraska

2008

A gel-based reference map of the porcine hepatocyte proteome

Thomas J. Caperna

USDA-ARS, thomas.caperna@ars.usda.gov

Amy E. Shannon

USDA-ARS, amy.shannon@ars.usda.gov

Wesley M. Garrett

USDA-ARS, wesley.garrett@ars.usda.gov

Follow this and additional works at: https://digitalcommons.unl.edu/usdaarsfacpub

Part of the Agricultural Science Commons

Caperna, Thomas J.; Shannon, Amy E.; and Garrett, Wesley M., "A gel-based reference map of the porcine hepatocyte proteome" (2008). Publications from USDA-ARS / UNL Faculty. 687.

https://digitalcommons.unl.edu/usdaarsfacpub/687

This Article is brought to you for free and open access by the U.S. Department of Agriculture: Agricultural Research Service, Lincoln, Nebraska at DigitalCommons@University of Nebraska - Lincoln. It has been accepted for inclusion in Publications from USDA-ARS / UNL Faculty by an authorized administrator of DigitalCommons@University of Nebraska - Lincoln. 


\title{
A gel-based reference map of the porcine hepatocyte proteome ${ }^{\text {tr }}$
}

\author{
Thomas J. Caperna*, Amy E. Shannon, Wesley M. Garrett \\ Animal Biosciences and Biotechnology Laboratory, Animal and Natural Resources Institute, USDA/ARS, \\ Beltsville Agricultural Research Center, USDA, Beltsville, MD, United States
}

Received 29 December 2006; received in revised form 21 December 2007; accepted 22 December 2007

\begin{abstract}
The overall goal of our research is to characterize and identify gene expression profiles of porcine hepatic cells. In this study, we have prepared two-dimensional electrophoresis maps of cytosol and membrane fractions from freshly prepared hepatocytes which were pooled from three crossbred pigs $(35-69 \mathrm{~kg}$ ). Following isoelectric focusing with three $\mathrm{pH}$ range immobilized $\mathrm{pH}$ gradient strips ( $\mathrm{pH} 3-6,5-8$ and 7-10) and staining the second dimension gels with colloidal Coomassie blue, 728 protein spots were picked and digested with trypsin. Extracted tryptic peptides were initially subjected to matrix-assisted laser desorption/ionization-time of flight mass spectrometry (MALDI-TOF-MS) analysis for identification of proteins by peptide mass fingerprinting (PMF). Proteins which were not identified by PMF were analyzed by liquid chromatography-tandem MS. Utilizing publicly available databases [NCBInr, Swiss Prot and expressed sequence tags (EST)], 648 proteins were identified. Of those, 282 were unique proteins and greater than $90 \%$ of proteins spots contained single proteins. These data represent the first comprehensive proteomic analysis of porcine hepatocytes and will provide a database for future investigations of endocrine regulation of gene expression and metabolic processes in vitro.
\end{abstract}

Published by Elsevier Inc.

Keywords: Pig hepatocytes; 2D-PAGE; MALDI-TOF-MS; LCMS/MS

\section{Introduction}

There is growing interest in porcine hepatocyte models for use in the investigation of swine metabolic processes [1-4], as well as, in human clinical applications for transplantation/artificial liver support [5] or toxicological analyses [6]. In all cases, whether fresh

\footnotetext{
Mention of trade name, proprietary product or vendor does not constitute a guarantee or warranty of the product by the U.S. Department of Agriculture or imply its approval to the exclusion of other products or vendors that may also be suitable.

* Corresponding author at: USDA-ARS, ANRI, Animal Biosciences and Biotechnology Laboratory, Building 200, Room 202, BARC-East, Beltsville, MD 20705, United States. Tel.: +1 301504 8506; fax: +1 3015048623 .

E-mail address: thomas.caperna@ars.usda.gov (T.J. Caperna).
}

or cultured cells are utilized, an understanding of gene expression at both the mRNA level and at the protein level will improve our understanding of regulatory processes and hepatic function. Indeed, a proteomic approach has been successfully used to assess the effects of physical manipulation and cell harvesting techniques on distribution and/or loss of proteins in rat hepatocytes [7]. In our laboratory, both short-term hepatocyte cultures on collagen [8,9] and long-term (weeks to months) cultures of adult hepatocytes (unpublished) and hepatic stem cells [10] are routinely employed and protein expression profiles during these culture periods are critical to interpret hormonal effects on differentiated cell function. Thus, our aim was to prepare a comprehensive database of the expressed proteins present in freshly prepared hepatocytes to understand potential changes due to culture. Our initial approach is presented here, where 
basic membrane and cytosol fractions were prepared and proteins were separated by two-dimensional polyacrylamide gel electrophoresis (2D-PAGE) and followed by identification with mass spectrometry to catalog the major proteins present in isolated hepatocytes. Our goal was to separate analytical quantities of proteins to yield single discrete protein spots for future comparisons using quantitative 2D-PAGE techniques. Using this approach we have successfully identified over 600 proteins. In addition, by using the apparent molecular weight of separated proteins, a more accurate interpretation of MS spectra and a high level of confidence in assigning protein identifications can be achieved, compared to non-gel based techniques.

\section{Materials and methods}

\subsection{Reagents}

Chemicals for electrophoresis including acrylamide, bis-acrylamide, $N, N, N^{\prime}, N^{\prime}$-tetra-methyl-ethylenediamine (TEMED), ammonium persulfate, agarose, (3-[3-cholamidopropyl)dimethylammonio]-1propanesulfonate (CHAPS), Triton-X 100, ampholytes (Bio-Lytes, pH 3-10), Bromophenol blue (BPB), iodoacetamide, and sodium dodecyl sulfate (SDS) were purchased from Bio-Rad (Hercules, CA). TrizmaBase (Tris), ethylenediaminetetraacetic acid (EDTA), diethyldithicarbamate (DEDTC), dithiothreitol (DTT), octyl glucoside, glycerol, glycine, ammonium sulfate, Coomassie blue G-250, thiourea, and trichloroacetic acid (TCA) were purchased from Sigma (St. Louis, MO). Urea was from Pierce (Sequanal grade, Rockford IL). Chemicals used during sample prep for MS analysis including acetonitrile $(\mathrm{ACN})$ and ammonium bicarbonate were from Sigma. Methanol, chloroform and acetic acid were from Fisher (Suwanee, GA), and trifluoroacetic acid (TFA) was from J.T. Baker (Phillipsburg, NJ). All other chemicals were reagent or HPLC grade.

\subsection{Hepatocyte preparation}

Care and treatment of all pigs in this study were approved by the Institutional Animal Care and Use Committee of the U.S. Department of Agriculture. Crossbred barrows (Landrace $\times$ York $\times$ Poland China, $n=3,52 \pm 10 \mathrm{~kg}$ ) were fully fed a corn-soy diet prior to stunning by electric shock and exsanguination. Livers were immediately excised and the left lateral lobe was removed. Hepatocytes were isolated by a two-step collagenase digestion procedure essentially as previously described $[9,11]$, where only a small portion (approximately $80 \mathrm{~g}$ ) of the lateral lobe was used. Viability of hepatocytes isolated by low speed centrifugation was $89 \pm 2.5 \%$ by Trypan blue dye exclusion and aliquots were frozen at $-80{ }^{\circ} \mathrm{C}$ until used. Cytosol and membrane fractions were prepared by centrifugation and differential solubilization in octylglucoside as described by Ruiz-Cortés et al. [12]. Purified hepatocytes from the three pigs were thawed on ice, pooled, homogenized by brief exposure to ultrasound in buffer $[2 \mathrm{mM}$ octylglucoside, $1 \mathrm{mM}$ DEDTC, $10 \mathrm{mM}$ EDTA in $50 \mathrm{mM}$ Tris, $\mathrm{pH} \mathrm{8]} \mathrm{and} \mathrm{centrifuged} \mathrm{at} 30,000 \mathrm{~g}$ for $60 \mathrm{~min}$ at $4{ }^{\circ} \mathrm{C}$. The supernatant (cytosol) was harvested and the particulate fraction was solubilized by ultrasound in $20 \mathrm{mM}$ Tris containing $50 \mathrm{mM}$ EDTA, $0.1 \mathrm{mM}$ DEDTC and $32 \mathrm{mM}$ octylglucoside, and centrifuged at $16,000 \mathrm{~g}$ for $15 \mathrm{~min}$ at $4{ }^{\circ} \mathrm{C}$. The insoluble pellet was discarded and the supernatant was aspirated and considered to be the membrane fraction. All buffers contained standard mammalian protease inhibitor cocktail $(1 \mu \mathrm{l} / \mathrm{ml}$, P-8340, Sigma). Cytosol and membrane fractions were precipitated by addition of $8-10$ volumes of cold chloroform:methanol (4:1), vortexed, sonicated and incubated on ice for $10 \mathrm{~min}$. The solution was centrifuged at $3000 \mathrm{~g}$ for $10 \mathrm{~min}$ at $4{ }^{\circ} \mathrm{C}$. Supernatant solution was discarded and methanol $(5 \mathrm{ml})$ was added to the pellet which was sonicated and centrifuged as before. The final pellet was vacuum dried to remove residual methanol and resuspended in re-hydration buffer (RHB): $8 \mathrm{M}$ urea, $1 \mathrm{M}$ thiourea, $50 \mathrm{mM}$ DTT, $4 \%$ CHAPS, $0.5 \%$ Bio-Lytes (pH $3-10$ ), and $0.001 \% \mathrm{BPB}$, using mechanical disruption and sonication. Insoluble material was removed by centrifugation at $15,000 \mathrm{~g}$ for $2 \mathrm{~min}$ at room temperature and cell material was stored at $-80^{\circ} \mathrm{C}$. Concentration of protein for all samples was determined by the method of Lowry following precipitation in 7\% TCA and $0.07 \%$ Triton-X 100 [13]. BSA was used as a standard and RHB buffer was used as background.

\subsection{Two-dimensional polyacrylamide gel electrophoresis}

The first dimension isoelectric focusing (IEF) was performed using $11 \mathrm{~cm}$ immobilized $\mathrm{pH}$ gradient (IPG) gel strips (pH 3-6, 5-8 or 7-10, Bio-Rad) in the IPGphor II system (GE Healthcare, Piscataway, NJ). In-gel re-hydration of $\mathrm{pH}$ 5-8 IPG strips was performed in the presence of $200 \mu \mathrm{g}$ protein in a total volume $200 \mu \mathrm{l}$ RHB; additional RHB was prepared fresh as needed to dilute the protein sample. The strips were passively re-hydrated for $1 \mathrm{~h}$ at $20^{\circ} \mathrm{C}$, followed by active rehydration at $50 \mathrm{~V}$ for $12-15 \mathrm{~h}$ and settings for protein 
focusing were: $500 \mathrm{~V}$ for $1 \mathrm{~h}$, then elevated to $8000 \mathrm{~V}$ maximum to a total of $46 \mathrm{kVh}$. The focused strips were rinsed in $\mathrm{dH}_{2} \mathrm{O}$ and stored at $-80^{\circ} \mathrm{C}$. For the $\mathrm{pH} 3-6$ and 7-10 strips, overnight passive re-hydration was performed with $200 \mu \mathrm{l}$ RHB alone. Protein $(400-500 \mu \mathrm{g}$ in $400 \mu \mathrm{l}$ RHB) was loaded at the anodic electrode via a paper bridge using the IPGphor II manifold system (GE Healthcare), according to the manufacturer's instructions. In addition to the $\mathrm{dH}_{2} 0$ wick, $300 \mu \mathrm{l}$ of RHB containing $3.5 \%$ DDT was loaded onto a pad which was placed upon the cathode end of each pH 7-10 IPG strip as suggested by Hoving et al. [14]. Isoelectric focusing was performed by ramping the voltage to a maximum of $6000 \mathrm{~V}$ and terminated at 20,000 Vh. Focused strips were rinsed in $\mathrm{dH}_{2} \mathrm{O}$ and stored at $-80^{\circ} \mathrm{C}$.

For the second dimension electrophoresis, the IPG gel strips were incubated with equilibration buffer $(0.4 \mathrm{M}$ Tris- $\mathrm{HCl} \mathrm{pH} 8.8,6 \mathrm{M}$ urea, 20\% glycerol, 2\% SDS, $1 \%$ DTT, $0.001 \% \mathrm{BPB}$ ) for $5 \mathrm{~min}$; it was removed and fresh buffer was added for an additional $15 \mathrm{~min}$. Strips were then incubated in the same equilibration buffer, without DTT, but containing $2.5 \%$ iodoacetamide for an additional $15 \mathrm{~min}$. Finally, excess iodoacetamide was removed by soaking strips ( $5 \mathrm{~min}$ ) in buffer containing equilibration buffer with $1 \%$ DTT. Each strip was rinsed in $\mathrm{dH}_{2} \mathrm{O}$ and subsequently placed onto a $12 \%$ polyacrylamide gel $(16 \mathrm{~cm} \times 20 \mathrm{~cm})$ and run with a Tris-glycine buffer system as described by Laemmli [15]. Strips were overlayed with $2.5 \%$ low melting agarose sealing solution $(0.375 \mathrm{M}$ Tris base, $0.1 \%$ SDS, $0.01 \mathrm{M}$ DTT and $0.001 \% \mathrm{BPB}, \mathrm{pH}$ 8.9). Electrophoresis was performed, using the PROTEAN II xi system (Bio-Rad) at $25^{\circ} \mathrm{C}$ with $2 \times$ buffer solution [16] in the top chamber $(0.38 \mathrm{M}$ glycine, $0.5 \mathrm{M}$ Tris, $0.2 \% \mathrm{SDS}, \mathrm{pH} 8.3$ ) and a $1 \times$ buffer solution in the bottom chamber running at $35 \mathrm{~mA} / \mathrm{gel}$ for approximately $1000 \mathrm{Vh}$. Proteins were visualized by staining gels with colloidal Coomassie blue [17]. Briefly, gels were fixed overnight in 50\% ethanol and 3\% phosphoric acid, followed by 3 washes with $\mathrm{dH}_{2} \mathrm{O}$. Gels were pre-stained for $1 \mathrm{~h}$ in $34 \%$ methanol, $17 \%$ ammonium sulfate and $3 \%$ phosphoric acid and finally stained in the same solution containing Coomassie blue G-250 $(0.066 \%)$ for 3 days. The gels were rinsed and stored in a $10 \%$ ammonium sulfate solution and scanned using laser densitometry (PDSI, GE Healthcare). Two-to-four gels were run for each condition ( $\mathrm{pH}$ range and fraction) and spots were picked from a representative gel.

\subsection{In-gel digestion of proteins}

Protein spots were excised from the stained gel and stored in $\mathrm{dH}_{2} \mathrm{O}$ at $-80^{\circ} \mathrm{C}$. Thawed gel plugs were first de-stained with a standard gel de-staining solution $\left(\mathrm{dH}_{2} 0\right.$ :methanol:acetic acid [4.5:4.5:1]), rinsed in $\mathrm{dH}_{2} \mathrm{O}$ (5 min) and finally de-stained in 50\% ACN containing $25 \mathrm{mM}$ ammonium bicarbonate $(3 \mathrm{~min} \times 15 \mathrm{~min})$. The gel plugs were dehydrated with $100 \%$ ACN (5 min), dried under vacuum, and then re-swollen with 10 or $20 \mu \mathrm{l}$ of $10 \mu \mathrm{g} / \mathrm{ml}$ trypsin (modified porcine trypsin, sequencing grade, Promega, Madison, WI) in $25 \mathrm{mM}$ ammonium bicarbonate, $\mathrm{pH}$ 8.0. An additional $30 \mu \mathrm{l} 25 \mathrm{mM}$ ammonium bicarbonate buffer was added to cover the gel plugs. Digestion was performed overnight at $37^{\circ} \mathrm{C}$. The resulting tryptic fragments were extracted with 5\% TFA in $50 \% \mathrm{ACN}$ with sonication for $60 \mathrm{~min}$, twice. The extracts were dried to completeness by vacuum centrifugation and then dissolved in 50\% ACN and 0.1\% TFA.

\subsection{Protein identification}

\subsubsection{Mass spectrometry}

A matrix-assisted laser desorption/ionizationtime of flight mass spectrometer (Voyager DE-STR MALDI-TOF-MS, Applied Biosystems, Framingham, MA) operated in positive ion reflector mode was used to analyze tryptic peptides by peptide mass fingerprinting (PMF). Samples $(0.5 \mu \mathrm{l})$ were co-crystallized with freshly prepared a-cyanohydroxycinnamic acid (re-crystalized from Sigma \#C-2020) matrix in 50\% ACN and $0.1 \%$ TFA $(0.5 \mu \mathrm{l})$ directly onto a target plate. Spotted samples were further desalted by addition of $0.1 \%$ TFA $(3 \mu \mathrm{l})$ which was immediately removed by vacuum. Spectra were acquired with 75 shots of a $337 \mathrm{~nm}$ Nitrogen Laser operating at $20 \mathrm{~Hz}$ and were calibrated using the porcine trypsin autolysis peaks at $\mathrm{m} / \mathrm{z} 842.51$ and 2,211.10 as internal standards. Samples which were not initially identified by PMF were vacuum-dried, re-suspended in $20 \mu \mathrm{l} 5 \% \mathrm{ACN}, 0.1 \%$ formic acid and subjected to MS/MS analysis (Thermo Finnigan LCQ DecaXP plus ion trap mass spectrometer, San Jose, CA). Peptides were separated by reverse phase chromatography using a $30 \mathrm{~min} 5-60 \%$ ACN gradient in $0.1 \%$ TFA. The instrument was operated with a duty cycle that acquired MS/MS spectra on the three most abundant ions following a survey scan from 400 to $1600 \mathrm{kDa}$. Dynamic exclusion was employed to prevent the continuous analysis of the same ions. Once two MS/MS spectra had been acquired from any given ion, the parent mass was placed on an exclusion list for the duration of $1.5 \mathrm{~min}$. The raw data were processed by Sequest to generate DTA files for database searching. The merge.pl script from Matrix Science was used to convert Sequest DTA files into a single generic file for searching in Mascot. 


\subsubsection{Data analysis}

Protein identification by PMF was performed by searching the National Center for Biotechnology Information non-redundant (NCBInr) and SwissProt primary databases using the Mascot search engine (http://www.matrixscience.com), which uses a probability based scoring system [18]. The following parameters were used for database searches: monoisotopic mass, $25 \mathrm{ppm}$ mass accuracy, trypsin as digesting enzyme with 1 missed cleavage allowed and carbamidomethylation of cysteine, oxidation of methionine, $\mathrm{N}$-terminal pyroglutamic acid from glutamic acid or glutamine as allowable variable modifications; taxonomy was limited to Mammalia. To qualify the MALDI-TOF-MS data as a positive identification, a protein's score (MOWSE) was equal to or exceeded the minimum significant score (70 and 60 for NCBInr and SwissProt, respectively). For LC MS/MS analyses, if the primary databases did not yield a positive identification, "EST_others" was queried and

$\mathrm{pH} 5$

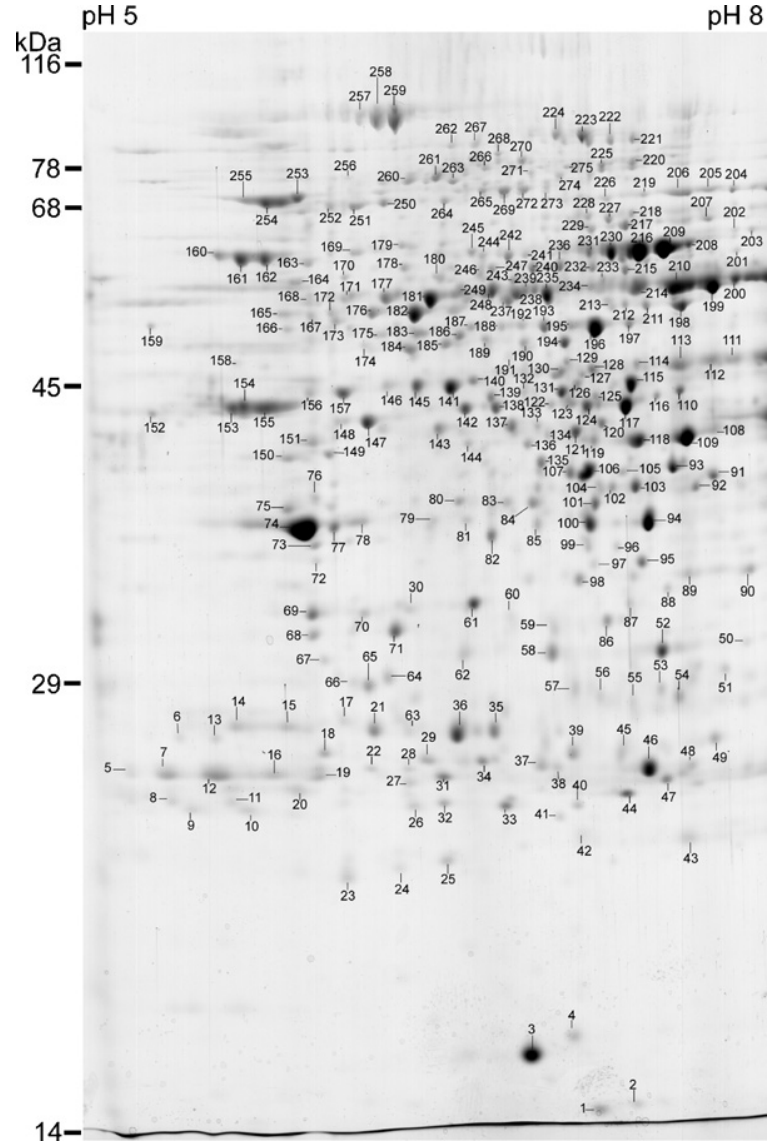

Fig. 1. Colloidal Coomassie stained 2D-PAGE of porcine hepatocyte cytosol proteins. Proteins were separated in the first dimension on a pH 5-8, $11 \mathrm{~cm}$ IPG strip. The numbered spots were prepared for MS analysis and the combined data are presented in Table 1 as gel \# 1 . significant sequence matches to swine ESTs were further Blasted to the primary databases. Positive identification of proteins by MS/MS analysis required a minimum of two unique peptides, both with significant ion scores and with an apparent molecular weight within approximately $10 \mathrm{kDa}$ of the expected mass of each protein.

\section{Results and discussion}

Preliminary 2D-PAGE separation of porcine liver proteins using full-length ( $\mathrm{pH} 3-10)$ IPG strips revealed that the vast majority of proteins were observed between $\mathrm{pH} 5$ and 9 (data not shown) and using multiple narrow range IPG strips (pH 3-6, 5-8 and 7-10), the present study has confirmed those observations. Similar findings in the $\mathrm{p} I$ range of most observable proteins by 2D-PAGE have been reported for rat liver [19]. Because separation of proteins in the alkaline range is notoriously poor due to DTT migration we have employed paper-bridge loading with additional DTT at the cathodic electrode to improve separation of proteins in the $\mathrm{pH} 7-10$ range

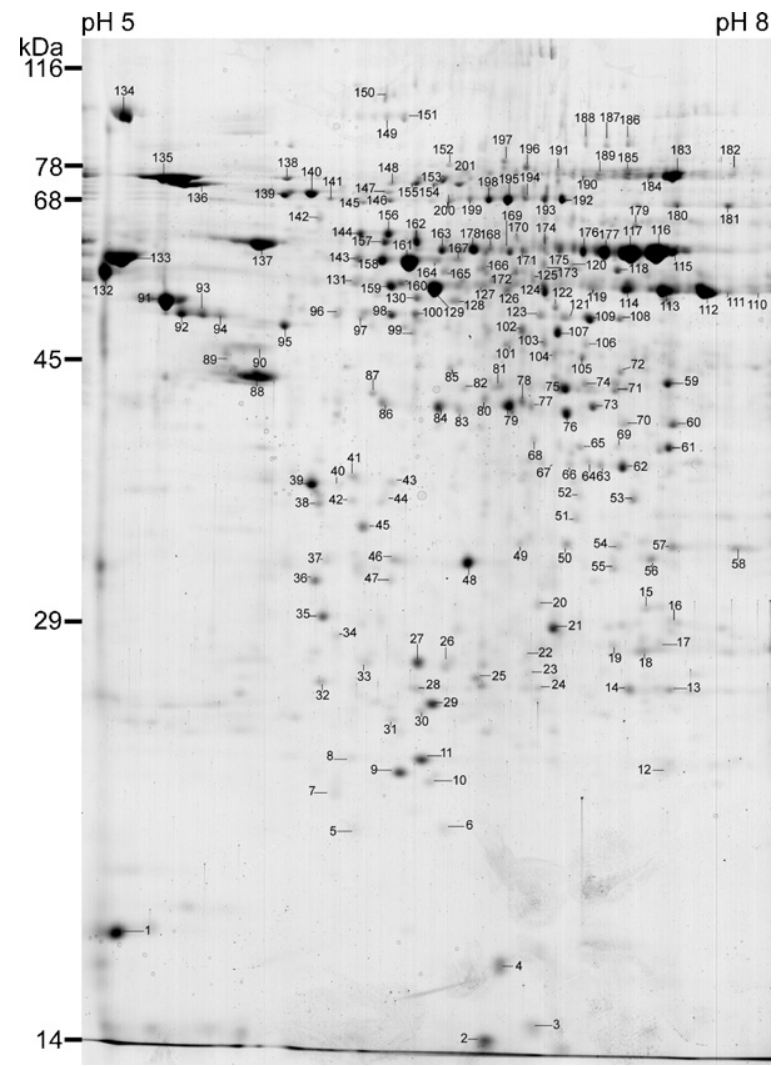

Fig. 2. Colloidal Coomassie stained 2D-PAGE of porcine hepatocyte membrane proteins. Proteins were separated in the first dimension on a pH 5-8, $11 \mathrm{~cm}$ IPG strip. The numbered spots were prepared for MS analysis and the combined data are presented in Table 1 as gel \# 2 . 


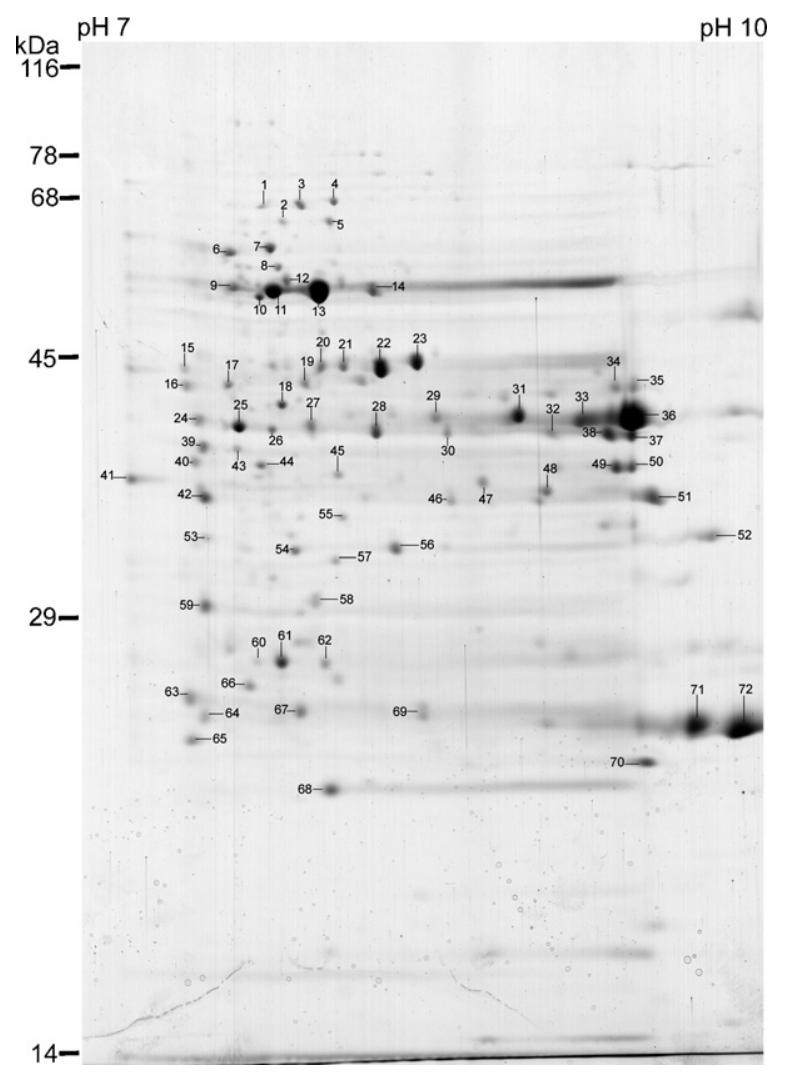

Fig. 3. Colloidal Coomassie stained 2D-PAGE of porcine hepatocyte cytosol proteins. Proteins were separated in the first dimension on a pH 7-10, $11 \mathrm{~cm}$ IPG strip. The numbered spots were prepared for MS analysis and the combined data are presented in Table 1 as gel \# 3 .

[14]. In our hands, standard in-gel re-hydration protein loading yielded poor separation for many proteins and this modification was absolutely necessary to yield consistent separation in the alkaline $\mathrm{pH}$ range.

Representative annotated gels are shown in Figs. 1-6 (viz., gel 1, pH 5-8 cytosol; gel 2, pH 5-8 membranes; gel 3, pH 7-10 cytosol; gel 4, pH 7-10 membranes; gel 5, $\mathrm{pH} 3-6$ cytosol and gel 6, pH 3-6 membranes). A total of 728 spots were picked and analyzed by mass spectrometry and 648 protein assignments were made. The detailed identification of each individual protein spot from these gels is included as supplemental data (Supplement 1), while summation of all unique proteins and their location on each gel map are provided in Table 1. As listed, 282 unique proteins were identified and represent the products of 280 unique genes. The noted exceptions were 17-beta estradiol dehydrogenase where both the 80 and $32 \mathrm{kDa}$ active isoforms [20] were detected in gel 4, and multiple N-terminal and a C-terminal domains of carbamoyl phosphate synthetase were observed in both the membrane and cytosolic gels. The full-length $164 \mathrm{kDa}$

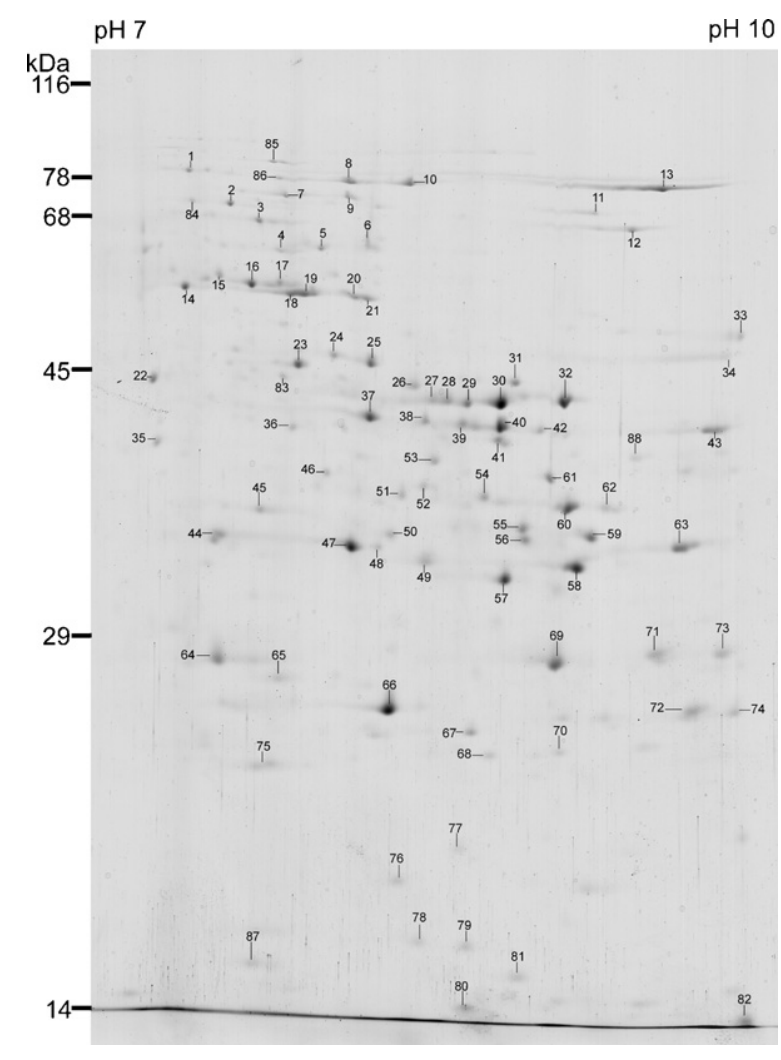

Fig. 4. Colloidal Coomassie stained 2D-PAGE of porcine hepatocyte membrane proteins. Proteins were separated in the first dimension on a pH 7-10, $11 \mathrm{~cm}$ IPG strip. The numbered spots were prepared for MS analysis and the combined data are presented in Table 1 as gel \# 4.

protein was not observed and in all cases peptides encompassing either the $\mathrm{C}$-terminal or $\mathrm{N}$-terminal domains, but not both, were noted. These lower $60-80 \mathrm{kDa}$ molecular weight isoforms of carbamoyl phosphate synthetase have been recognized in baboon liver and are apparently up-regulated during inflammation [21]. Additional multiple isoforms (or spots) of various proteins appearing in either fraction and across gels are a combination of posttranslational modifications, other potential proteolytic products (precursor vs. mature), and may also be the result of the crude membrane-cytosol preparation with frozen cells.

By utilizing MALDI-TOF-MS (PMF) as an initial screening tool, 349 or $53.9 \%$ of the 648 proteins were positively identified. Of those, only 167 (47.9\%) were assignments based on Sus scrofa identities which indicates that as more sequences and annotations from pig are available in public domain databases, higher percentages of identifications by PMF could be expected. Only those spots which could not be positively identified by PMF were prepared for ESI-MS/MS analysis. Of the potential 379 spots which were not identified 
Table 1

Summary of 282 unique protein assignments of porcine hepatocyte cytosol and membrane fractions in six different gels: gel 1, cytosol pH 5-8; gel 2, membranes pH 5-8; gel 3, cytosol pH 7-10, gel 4, membranes pH 7-10; gel 5, cytosol pH 3-6 and gel 6, membranes pH 3-6

\begin{tabular}{|c|c|c|}
\hline Gel and spot number & Protein identification & Representative accession no. \\
\hline $5-25$ & $\begin{array}{l}\text { 14-3-3 Protein beta/alpha (Protein kinase } \mathrm{C} \text { inhibitor } \\
\text { protein 1) (KCIP-1) }\end{array}$ & 1433B_BOVIN \\
\hline $5-4$ & $\begin{array}{l}\text { 14-3-3 Protein gamma (Protein kinase } \mathrm{C} \text { inhibitor } \\
\text { protein 1) }\end{array}$ & 108451 \\
\hline $3-48$ & 15-Oxoprostaglandin 13-reductase & 2947100 \\
\hline $4-8,10$ & 17-Beta-estradiol dehydrogenase & 47523670 \\
\hline $4-50,56$ & $\begin{array}{l}\text { 17-Beta-estradiol dehydrogenase ( } \mathrm{N} \text {-terminal active } \\
32 \mathrm{kDa} \text { dehydrogenase) }\end{array}$ & 1090092 \\
\hline $4-86$ & 17-Beta-hydroxysteroid dehydrogenase 4 & DHB4_MOUSE \\
\hline $3-52 ; 4-63$ & 2,4-Dienoyl-CoA reductase & 37934198 \\
\hline $4-70$ & 2-Cys Peroxiredoxin, Hbp23 & 6435547 \\
\hline $2-101$ & $\begin{array}{l}\text { 2-Oxoisovalerate dehydrogenase subunit alpha, } \\
\text { mitochondrial precursor }\end{array}$ & ODBA_BOVIN \\
\hline $4-65$ & $\begin{array}{l}\text { 3,2-trans-Enoyl-CoA isomerase, mitochondrial } \\
\text { (D3D2_HUMAN) } 1099293 \text { MARC 4PIG Sus scrofa } \\
\text { cDNA 3' }\end{array}$ & 59777590 \\
\hline $4-42$ & $\begin{array}{l}\text { 3,2-trans-Enoyl-CoA isomerase, PECI-peroxisomal } \\
\text { (PECI_HUMAN) CJ000466 swine cDNA clone } \\
\text { LVR01E040088, } 5^{\prime}\end{array}$ & 54483061 \\
\hline $3-69 ; 4-66$ & 3-Hydroxyacyl-CoA dehydrogenase type-2 & HCD2_BOVIN \\
\hline $1-71$ & 3-Hydroxyanthranilate 3,4-dioxygenase & 3HAO_RAT \\
\hline $1-56$ & 3-Hydroxybutyrate dehydrogenase type 2 & BDH2_BOVIN \\
\hline $1-68 ; 2-36 ; 6-10$ & 3-Hydroxyisobutyrate dehydrogenase & 3HIDH_RAT \\
\hline $4-27,28,29,30$ & 3-Ketoacyl-CoA thiolase & THIK_HUMAN \\
\hline $4-30$ & 3-Ketoacyl-CoA thiolase A & THIKA_RAT \\
\hline $4-34$ & 3-Ketoacyl-CoA thiolase, long chain & 47522760 \\
\hline $3-34,35 ; 4-32$ & 3-Ketoacyl-CoA thiolase, mitochondrial & THIM_RAT \\
\hline $1-85,94,100 ; 3-42$ & 3-Oxo-5-beta-steroid 4-dehydrogenase & AK1D1_HUMAN \\
\hline $1-210$ & 3-Phosphoglycerate dehydrogenase & 13928850 \\
\hline $5-8 ; 6-7$ & $\begin{array}{l}40 \mathrm{~S} \text { ribosomal protein SA (p40) }(34 / 67 \mathrm{kDa} \text { laminin } \\
\text { receptor) }\end{array}$ & RSSA_CRIGR \\
\hline $1-141,145,146$ & 4-Hydroxyphenylpyruvic acid dioxygenase & 47523532 \\
\hline $1-172,176,182 ; 2-130$ & $\begin{array}{l}\text { 4-Trimethylaminobutyraldehyde dehydrogenase } \\
\text { (Aldehyde DH 9A1) }\end{array}$ & AL9A1_BOVIN \\
\hline $2-41,43$ & $60 \mathrm{~S}$ acidic ribosomal protein $\mathrm{P} 0$ (L10E) & RLA0_BOVIN \\
\hline $4-29$ & $\begin{array}{l}\text { Acetyl-CoA acetyltransferase (Acetoacetyl-CoA } \\
\text { thiolase) }\end{array}$ & THIL_MOUSE \\
\hline $1-223,224$ & Aconitase (Iron regulatory protein-1) & IREB1_RABIT \\
\hline $4-85$ & $\begin{array}{l}\text { Aconitate hydratase, mitochondrial precursor } \\
\text { (Aconitase) }\end{array}$ & ACON_PIG \\
\hline $2-88$ & Actin (gamma) & 809561 \\
\hline $\begin{array}{l}1-76,153,154,155 ; 5-40,41 \\
53,54,60,62 ; 6-12,13\end{array}$ & Actin, cytoplasmic 1 (Beta-actin) & ACTB_BOVIN \\
\hline $1-174$ & Actin-like protein 3 (Actin-related protein 3 ) & ARP3_MOUSE \\
\hline $3-5$ & $\begin{array}{l}\text { Acyl CoA synthetase, medium chain (Predicted) } \\
\text { [gi: } 76653089, \text { Bos taurus] } 1518577 \text { MARC 3PIG } \\
\text { cDNA 3' }\end{array}$ & 87214063 \\
\hline $4-7$ & Acyl coenzyme A synthetase, long-chain 1 & 50604627 \\
\hline $1-121,137 ; 2-76,2-79$ & $\begin{array}{l}\text { Acyl-CoA dehydrogenase (Butyryl-CoA DH-short } \\
\text { chain) }\end{array}$ & ACADS_PIG \\
\hline $2-71$ & Acyl-Coa dehydrogenase, chain A, medium-chain & 40889734 \\
\hline $1-123 ; 2-81$ & Acyl-Coa dehydrogenase, medium chain, chain B & 640353 \\
\hline $1-117 ; 2-75$ & Acyl-CoA dehydrogenase, medium-chain specific & ACADM_PIG \\
\hline $1-120,137,143 ; 2-79,83,84,86$ & $\begin{array}{l}\text { Acyl-CoA dehydrogenase, short/branched chain } \\
\text { specific }\end{array}$ & ACDSB_RAT \\
\hline $1-133$ & Acyl-Coenzyme A dehydrogenase family, member 8 & 7656849 \\
\hline
\end{tabular}


Table 1 (Continued)

\begin{tabular}{|c|c|c|}
\hline Gel and spot number & Protein identification & Representative accession no. \\
\hline $4-9$ & $\begin{array}{l}\text { Acyl-coenzyme A oxidase } 1 \text { 1(Palmitoyl-CoA } \\
\text { oxidase) }\end{array}$ & ACOX1_HUMAN \\
\hline $1-139$ & Adenosine kinase isoform $b$ isoform 1 (Predicted) & 57085123 \\
\hline $1-92$ & Aflatoxin B1 aldehyde reductase member 4 & ARK74_HUMAN \\
\hline $1-61 ; 2-46,48$ & $\begin{array}{l}\text { Agmatinase, mitochondrial precursor (Agmatine } \\
\text { ureohydrolase) }\end{array}$ & SPEB_HUMAN \\
\hline $1-195,197 ; 2-108$ & $\begin{array}{l}\text { Alanine-glyoxylate aminotransferase } 2 \text {, } \\
\text { mitochondrial precursor }\end{array}$ & AGT2_RAT \\
\hline $1-178,264 ; 2-195,198,199,200$ & Albumin & 833798 \\
\hline $3-31,32,33,36 ; 4-38,40,41$ & Alcohol dehydrogenase 1 & ADH1_MOUSE \\
\hline $3-28 ; 4-36$ & Alcohol dehydrogenase class II isozyme 1 & 3912976 \\
\hline $1-257,258,259 ; 2-149,151$ & $\begin{array}{l}\text { Aldehyde dehydrogenase } 1 \text { family, member L1 } \\
\text { (10-FTHFDH) }\end{array}$ & FTHFD_MOUSE \\
\hline $1-259$ & Aldehyde dehydrogenase 1 family, member L2 & 77681579 \\
\hline $\begin{array}{l}1-171,177,181,238,248 \\
2-127,129,131,159,160,165\end{array}$ & Aldehyde dehydrogenase 2, mitochondrial & 113205888 \\
\hline $3-12$ & $\begin{array}{l}\text { Aldehyde dehydrogenase family } 6 \text {, subfamily A1 } \\
\text { (Aldh6a1) }\end{array}$ & 21410418 \\
\hline $1-235,237,238 ; 2-122,126$ & $\begin{array}{l}\text { Aldehyde dehydrogenase family } 7 \text { member A } 1 \\
\text { (Antiquitin-1) }\end{array}$ & AL7A1_HUMAN \\
\hline $1-91 ; 3-44$ & $\begin{array}{l}\text { Aldehyde Reductase (aldo-keto reductase family } 1 \\
\text { member A1) }\end{array}$ & AK1A1_PIG \\
\hline $3-46$ & Aldo-keto reductase family 1 member $\mathrm{C} 1$, putative & 113205730 \\
\hline $1-188,193,196 ; 2-109$ & Alpha enolase & ENOA_BOVIN \\
\hline $1-147,148 ; 2-87$ & Aminoacylase I & 1845 \\
\hline $5-18$ & $\begin{array}{l}\text { Annexin A5 (Annexin V) (Lipocortin V) } \\
\text { (Endonexin II) (Calphobindin I) (CBP-I) }\end{array}$ & ANXA5_BOVIN \\
\hline $1-250$ & Annexin VI & 1842109 \\
\hline $2-45$ & Apolipoprotein E & 47523674 \\
\hline $1-106 ; 2-65$ & Arginase I & 15281140 \\
\hline $1-188$ & Argininosuccinate lyase (Arginosuccinase) (ASAL) & 114160 \\
\hline $1-111,112 ; 3-21,23 ; 4-25$ & Argininosuccinate synthase & ASSY_RAT \\
\hline $4-43$ & Aspartate aminotransferase & 47522630 \\
\hline $3-18$ & Aspartate aminotransferase, cytosolic & 47522636 \\
\hline $1-159 ; 2-91 ; 5-24 ; 6-17,18$ & $\begin{array}{l}\text { ATP synthase } \mathrm{H}+\text { transporting F1 complex beta } \\
\text { subunit }\end{array}$ & 89574051 \\
\hline $2-11$ & ATP synthase, mitochondrial F0 complex, subunit d & 27807305 \\
\hline $1-111,112,113 ; 3-20,22 ; 4-23$ & Betaine-homocysteine $S$-methyltransferase & BHMT_MOUSE \\
\hline $1-138,142$ & Beta-ureidopropionase (Beta-alanine synthase) & BUP1_PONPY \\
\hline $1-185$ & $\begin{array}{l}\text { Bile acid CoA:amino acid } N \text {-acyltransferase } \\
\text { (BAAT_HUMAN) MI-P-CP1-nzc-1-24-0-UI.s1 } \\
\text { MI-P-CP1 3'cDNA. }\end{array}$ & 21551454 \\
\hline $1-44 ; 3-65$ & Biliverdin reductase B (flavin reductase (NADPH) & BLVRB_MOUSE \\
\hline $4-11$ & $\begin{array}{l}\text { Calcium-binding mitochondrial carrier protein } \\
\text { Aralar2 }\end{array}$ & CMC2_HUMAN \\
\hline $2-132 ; 5-22$ & Calreticulin precursor (CRP55) (partial sequence) & CALR_PIG \\
\hline $\begin{array}{l}1-261,266,270,274 \\
2-153,196,197\end{array}$ & $\begin{array}{l}\text { Carbamoyl-phosphate synthetase ( } \sim 80 \mathrm{kDa} \\
\mathrm{N} \text {-terminal domain) }\end{array}$ & CPSM_MOUSE \\
\hline $2-147,148,155$ & $\begin{array}{l}\text { Carbamoyl-phosphate synthetase } 1(\sim 70 \mathrm{kDa} \\
\text { N-terminal domain) }\end{array}$ & 8393186 \\
\hline $2-142$ & $\begin{array}{l}\text { Carbamoyl-phosphate synthetase } 1 \text { ( } \sim 65 \mathrm{kDa} \\
\text { N-terminal domain) }\end{array}$ & 8393186 \\
\hline $\begin{array}{l}1-220,225,228,245,272,273 \\
275 ; 2-185\end{array}$ & $\begin{array}{l}\text { Carbamoyl-phosphate synthetase I (C-terminal } \\
\text { domain) }\end{array}$ & 26324620 \\
\hline $3-58$ & $\begin{array}{l}\text { Carbonyl reductase [NADPH] } \\
\text { 20-beta-hydroxysteroid DH) }\end{array}$ & DHCA_PIG \\
\hline $4-71$ & Carbonyl reductase/NADP-retinol dehydrogenase & 47522860 \\
\hline
\end{tabular}


Table 1 (Continued)

\begin{tabular}{|c|c|c|}
\hline Gel and spot number & Protein identification & Representative accession no. \\
\hline $2-144,156,157,162,163,168,178$ & $\begin{array}{l}\text { Carboxylesterase precursor } \\
\text { (Proline-beta-naphthylamidase) }\end{array}$ & EST1_PIG \\
\hline $4-12$ & Carnitine $O$-palmitoyltransferase 2 & CPT2_MACFA \\
\hline $\begin{array}{l}1-208,209,216,230,231 ; 2-115 \\
116,174,175,176,177 ; 3-6\end{array}$ & Catalase & 12082093 \\
\hline $1-7,12,20 ; 5-28,29,30$ & Catechol $O$-methyltransferase & COMT_PIG \\
\hline $1-57$ & Cathepsin D & 56417363 \\
\hline $1-163$ & Chaperonin containing TCP 1 , subunit 8 (theta) & 73586947 \\
\hline $4-5$ & Choline dehydrogenase & 27501456 \\
\hline $5-19$ & Coatomer subunit epsilon (Epsilon-coat protein) & COPE_BOVIN \\
\hline $1-116,117$ & Cystathionase & 104295139 \\
\hline $2-1 ; 6-2,3$ & Cytochrome b5 & CYB5_PIG \\
\hline $2-3$ & $\begin{array}{l}\text { Cytochrome } \mathrm{C} \text { oxidase subunit } 5 \mathrm{~B} \text {, mitochondrial } \\
\text { precursor }\end{array}$ & COX5B_PIG \\
\hline $1-152 ; 5-41,42,43,44,52$ & Cytokeratin 18 & K1C18_MOUSE \\
\hline $1-158,166 ; 2-89,160 ; 5-44$ & Cytokeratin 8 & K2C8_BOVIN \\
\hline $1-75$ & cytosolic inorganic pyrophosphatase & 4583153 \\
\hline $2-61,69 ; 3-43 ; 4-35$ & D-Amino acid oxidase & 66086 \\
\hline $4-57$ & D-Beta-hydroxybutyrate dehydrogenase & 203921 \\
\hline $4-51$ & $\begin{array}{l}\text { Dehydrogenase/reductase SDR member } 1 \\
\text { (DHRS1_MOUSE) BW981110 swine cDNA clone } \\
\text { ITT010057H07, 5' }\end{array}$ & 74257950 \\
\hline $1-101$ & Delta-aminolevulinic acid dehydratase isoform $b$ & 86438477 \\
\hline $2-118$ & $\begin{array}{l}\text { Dihydrolipoyl dehydrogenase, mitochondrial } \\
\text { precursor }\end{array}$ & DLDH_PIG \\
\hline $2-100$ & $\begin{array}{l}\text { Dihydrolipoyllysine-residue succinyltransferase } \\
\text { component of 2-oxoglutarate dehydrogenase } \\
\text { complex, mitochondrial precursor }\end{array}$ & ODO2_PIG \\
\hline $1-202,203 ; 3-7$ & Dihydroxyacetone kinase & DAK_BOVIN \\
\hline $1-135$ & dimeric dihydrodiol dehydrogenase & 47523420 \\
\hline $1-221,222 ; 2-186,188$ & $\begin{array}{l}\text { Dimethylglycine dehydrogenase mitochondrial } \\
\text { precursor }\end{array}$ & M2GD_HUMAN \\
\hline $1-26,33$ & DJ-1 protein (Type 1 glutamine amidotransferase) & 67038668 \\
\hline $2-78$ & DnaJ (Hsp40) homolog, subfamily B, member 11 & 77735491 \\
\hline $3-56 ; 4-47,48$ & $\begin{array}{l}\text { Electron transfer flavoprotein alpha subunit } \\
\text { precursor }\end{array}$ & 35384836 \\
\hline $4-69$ & Electron transfer flavoprotein subunit beta & ETFB_PIG \\
\hline $2-179$ & $\begin{array}{l}\text { Electron transfer flavoprotein-ubiquinone } \\
\text { oxidoreductase, mitochondrial precursor }\end{array}$ & ETFD_PIG \\
\hline $5-20$ & Elongation factor 1 delta (translational) & 57164211 \\
\hline $5-5$ & Elongation factor 1-beta (EF-1-beta) & EF1B_BOVIN \\
\hline $1-128 ; 2-105$ & Elongation factor $\mathrm{Tu}$, mitochondrial precursor & EFTU_BOVIN \\
\hline $2-21$ & $\begin{array}{l}\text { Endoplasmic reticulum protein } 29 \text { isoform } 1 \\
\text { precursor }\end{array}$ & ERP29_HUMAN \\
\hline $1-87$ & Enoyl coenzyme A hydratase 1, peroxisomal & 90024980 \\
\hline $2-18 ; 3-60,61 ; 4-64$ & Enoyl-CoA hydratase, mitochondrial precursor & ECHM_BOVIN \\
\hline $4-13$ & $\begin{array}{l}\text { Enoyl-Coenzyme A hydratase/3-hydroxyacyl } \\
\text { Coenzyme A }\end{array}$ & 51493747 \\
\hline $1-241,242,244 ; 2-169$ & Epoxide hydrolase, soluble & HYES_PIG \\
\hline $1-80$ & $\begin{array}{l}\text { Ester hydrolase C11orf54 homolog (BW960903 } \\
\text { full-length enriched swine cDNA) }\end{array}$ & 71961233 \\
\hline $1-95,97 ; 3-53$ & Esterase D ( $S$-formylglutathione hydrolase) & ESTD_PIG \\
\hline $5-1$ & $\begin{array}{l}\text { Eukaryotic translation initiation factor 5A-1 } \\
\text { (eIF-5A-1) (eIF-5A1) }\end{array}$ & IF5A1_BOVIN \\
\hline $5-15$ & Eukaryotic translation initiation factor 6 (eIF-6) & IF6_BOVIN \\
\hline $4-18,19,20,21$ & F1-Atpase, chain A, mitchondrial & 1943080 \\
\hline $2-41$ & F-actin capping protein alpha- 1 subunit (Predicted) & 61821551 \\
\hline $2-2$ & Fatty acid binding protein-liver & FABPL_PIG \\
\hline
\end{tabular}


Table 1 (Continued)

\begin{tabular}{|c|c|c|}
\hline Gel and spot number & Protein identification & Representative accession no. \\
\hline $1-23$ & Ferritin heavy chain (Ferritin H subunit) & 47522776 \\
\hline $1-25$ & Ferritin L subunit & 10304378 \\
\hline $1-236,240,247$ & Formiminotransferase-cyclodeaminase & 47523624 \\
\hline $1-93,105,107 ; 3-39 ; 5-65$ & Fructose-1,6-bisphosphatase 1 (EC 3.1.3.11) & F16P1_PIG \\
\hline $3-32,37,38 ; 4-41$ & Fructose-bisphosphate aldolase B & ALDOB_HUMAN \\
\hline $1-117,122,124 ; 3-16$ & Fumarylacetoacetase (Beta-diketonase) & FAAA_HUMAN \\
\hline $1-98 ; 2-50$ & $\begin{array}{l}\text { Fumarylacetoacetate hydrolase domain containing } \\
2 \mathrm{~A}\end{array}$ & 7705608 \\
\hline $1-149$ & Galactokinase 1 & 110665600 \\
\hline $1-134$ & GDP-mannose pyrophosphorylase B & 29244556 \\
\hline 2-141 & $\begin{array}{l}\text { Glucose regulated protein } 75 \text { (Stress- } 70 \text { protein), } \\
\text { mitochondrial precursor }\end{array}$ & GRP75_HUMAN \\
\hline $2-135 ; 5-46 ; 6-21$ & $\begin{array}{l}\text { Glucose-regulated protein precursor (GRP 78) (Heat } \\
\text { shock } 70 \mathrm{kDa} \text { protein 5) }\end{array}$ & GRP78_MESAU \\
\hline $2-150$ & Glucosidase II & 47522680 \\
\hline $\begin{array}{l}\text { 1-199,210,214,233, 234,239; } \\
\quad 2-110,111 \\
\text { 112,113,114,119,125; 3-9,10; } \\
\text { 4-14 }\end{array}$ & $\begin{array}{l}\text { Glutamate dehydrogenase } 1 \text {, mitochondrial } \\
\text { precursor }\end{array}$ & DHE3_HUMAN \\
\hline $1-130,131$ & Glutamine synthetase & 73586743 \\
\hline $4-83$ & $\begin{array}{l}\text { Glutaryl-CoA dehydrogenase, mitochondrial } \\
\text { precursor }\end{array}$ & GCDH_PIG \\
\hline $1-27$ & Glutathione peroxidase, cytosolic & 47523488 \\
\hline $\begin{array}{l}1-19,37,46 ; 2-14 ; 3-63,71,72 \\
\quad 4-72\end{array}$ & Glutathione $S$-transferase (alpha M14) & GSTA1_PIG \\
\hline $1-52,58,62 ; 2-15,20 ; 3-59$ & Glutathione $S$-transferase (omega-1) & GSTO1_PIG \\
\hline $4-67$ & Glutathione $S$-transferase kappa 1 (Predicted) & 73978758 \\
\hline $3-64,67$ & Glutathione $S$-transferase mu 2 & 116047847 \\
\hline $3-64$ & Glutathione $S$-transferase mu 5 & 23065563 \\
\hline $1-17,19,38,47,48$ & $\begin{array}{l}\text { Glutathione } S \text {-transferase Y1 (Chain 3) (GST } \\
\text { class-mu) }\end{array}$ & 399829 \\
\hline $1-173$ & Glutathione synthetase & 4504169 \\
\hline $3-49,50 ; 4-61$ & $\begin{array}{l}\text { Glyceraldehyde-3-phosphate dehydrogenase } \\
\text { (GAPDH) }\end{array}$ & G3P_PIG \\
\hline $2-128$ & $\begin{array}{l}\text { Glycerate kinase (hypothetical } 54 \text { kDa protein, } \\
\text { LOC507949) }\end{array}$ & 114050933 \\
\hline $1-83,84$ & Glycerol-3-phosphate dehydrogenase, cytosolic & 2149959 \\
\hline $2-64$ & Glycerophosphate dehydrogenase (KIAA0089) & 577307 \\
\hline $1-129,189,190,194 ; 2-102,107$ & $\begin{array}{l}\text { Glycine amidinotransferase (L-arginine:glycine } \\
\text { amidinotransferase) }\end{array}$ & GATM_PIG \\
\hline $4-45$ & $\begin{array}{l}\text { Glycine- } N \text {-acyltransferase [gi:29135315], Bos } \\
\text { taurus, BP139133 swine cDNA library clone } \\
\text { LVRM10079D06, } 5^{\prime}\end{array}$ & 40386874 \\
\hline $2-31$ & GTP-binding protein SAR1b & SAR1B_BOVIN \\
\hline $1-14,15 ; 5-27$ & Guanidinoacetate $N$-methyltransferase & GAMT_BOVIN \\
\hline $1-184 ; 2-99$ & Guanosine diphosphate dissociation inhibitor 2 & 48675953 \\
\hline $1-18 ; 2-24,28,32$ & Heat shock $27 \mathrm{kDa}$ protein 1 & 50979116 \\
\hline $1-251,252 ; 2-145$ & Heat shock $70 \mathrm{kDa}$ protein 1A (HSP70.1) & HS70A_BOVIN \\
\hline $1-254,255 ; 2-139 ; 5-49,51$ & $\begin{array}{l}\text { Heat shock cognate } 71 \mathrm{kDa} \text { protein (Heat shock } \\
70 \mathrm{kDa} \text { protein } 8 \text { ) }\end{array}$ & HSP7C_HUMAN \\
\hline $\begin{array}{l}1-160,161,162 ; 2-137 ; 5-26,56 \\
\quad 57 ; 6-23\end{array}$ & Heat shock protein $($ Hsp60) & CH60_HUMAN \\
\hline $1-256$ & Heat shock protein (HSP90) & 47522774 \\
\hline $1-253 ; 2-140 ; 6-24$ & Heat shock protein 9A (GRP75) & 6754256 \\
\hline $2-134$ & $\begin{array}{l}\text { Heat shock protein (HSP } 90 \mathrm{kDa} \text { beta member } 1 \text {, } \\
\text { GRP94) }\end{array}$ & ENPL_PIG \\
\hline $1-20$ & Heme-binding protein & 58332866 \\
\hline $4-54,62$ & $\begin{array}{l}\text { Heterogeneous nuclear ribonucleoprotein A2/B1 } \\
\text { isoform } 2\end{array}$ & 32880197 \\
\hline
\end{tabular}


Table 1 (Continued)

\begin{tabular}{|c|c|c|}
\hline Gel and spot number & Protein identification & Representative accession no. \\
\hline $4-24$ & $\begin{array}{l}\text { Hydroxy steroid dehydrogenase like } 2 \\
\text { [gi:13195670] BP151282 swine cDNA clone } \\
\text { OVRM10072F02, } 5^{\prime}\end{array}$ & 40400755 \\
\hline $4-37$ & Hydroxyacid oxidase 1 (Glycolate oxidase) & HAOX1_MOUSE \\
\hline $4-53$ & Hydroxyacid oxidase 2 (peroxisomal, long chain) & HAOX2_HUMAN \\
\hline $1-51$ & Hydroxyacyl glutathione hydrolase & GLO2_MOUSE \\
\hline $4-59$ & $\begin{array}{l}\text { Hydroxyacyl-coenzyme A dehydrogenase, } \\
\text { mitochondrial precursor }\end{array}$ & HCDH_PIG \\
\hline $1-164 ; 5-68$ & Hydroxymethylglutaryl-CoA synthase, cytoplasmic & HMCS1_HUMAN \\
\hline $1-39$ & Hypoxanthine-guanine phosphoribosyltransferase & 2499938 \\
\hline $5-34$ & $\begin{array}{l}\text { Indolethylamine } N \text {-methyltransferase } \\
\text { (INMT_MOUSE) BP443228 swine cDNA clone } \\
\text { LVR010100C06 5' }\end{array}$ & 40433295 \\
\hline $1-115,126,127 ; 2-72 ; 4-31$ & Isocitrate dehydrogenase, NADP dependent & 6647554 \\
\hline $1-35 ; 2-19$ & Isopentenyldiphosphate isomerase & 48257093 \\
\hline $1-110 ; 2-59 ; 3-17 ; 4-22$ & $\begin{array}{l}\text { Isovaleryl-CoA dehydrogenase, mitochondrial } \\
\text { precursor }\end{array}$ & IVD_HUMAN \\
\hline $1-69$ & $\begin{array}{l}\text { Ketohexokinase (KHK_MOUSE) MPL384_4_A17 } \\
\text { MPL swine cDNA clone pSPORT1, } 5^{\prime} \text { ) }\end{array}$ & 26018027 \\
\hline $2-56$ & Lactamase, beta 2 & 7705793 \\
\hline $1-8,11 ; 5-31$ & Lactoylglutathione lyase (Glyoxalase I) & LGUL_HUMAN \\
\hline $1-50$ & L-Aspartate dehydrogenase (putative) & ASPD_MOUSE \\
\hline $1-239,248$ & Leucine aminopeptidase) (LAP, cytosolic) & AMPL_BOVIN \\
\hline $1-136$ & Leukocyte elastase inhibitor (LEI) Serpin B1 & 417185 \\
\hline $1-77$ & L-Lactate dehydrogenase B chain (LDH-B) & 1170738 \\
\hline $1-82$ & Malate dehydrogenase & 164543 \\
\hline $3-51 ; 4-60$ & Malate dehydrogenase, mitochondrial & 65932 \\
\hline $1-86$ & MAWD Binding Protein & 19743770 \\
\hline $4-15,17$ & Methylmalonate-semialdehyde dehydrogenase & MMSA_RAT \\
\hline $4-81$ & $\begin{array}{l}\text { Mitochondrial fission } 1 \text { protein (Fis1 homolog, } \\
\text { Tetratricopeptide repeat protein } 11 \text { ) }\end{array}$ & FIS1_RAT \\
\hline $2-192,193$ & $\begin{array}{l}\text { Mitochondrial respiratory complex } 1 \mathrm{i} \text { (succinate } \\
\text { dehydrogenase) chain A }\end{array}$ & 73535956 \\
\hline $4-6$ & Monoamine oxidase B & 49274643 \\
\hline $2-138$ & $\begin{array}{l}\text { NADH dehydrogenase (ubiquinone) Fe-S protein } 1 \text {, } \\
75 \mathrm{kDa} \text { precursor }\end{array}$ & 33519475 \\
\hline $2-30$ & $\begin{array}{l}\text { NADH dehydrogenase [ubiquinone] flavoprotein } 2 \text {, } \\
\text { mitochondrial precursor }\end{array}$ & NDUV2_MOUSE \\
\hline $2-34$ & NADH dehydrogenase $\mathrm{Fe}-\mathrm{S}$ protein 3 & 20071222 \\
\hline $1-42,43 ; 3-68$ & $\begin{array}{l}\text { Neuropolypeptide } \mathrm{h} 3 \\
\text { (Phosphatidylethanolamine-Binding Protein) }\end{array}$ & 913159 \\
\hline $1-73 ; 5-37$ & $\begin{array}{l}\text { Nicotinate-nucleotide pyrophosphorylase } \\
\text { (NADC_BOVIN) } 1113707 \text { MARC 4PIG Sus scrofa } \\
\text { cDNA 5' }\end{array}$ & 59808271 \\
\hline $1-21,36$ & $\begin{array}{l}\text { Non-selenium glutathione phospholipid } \\
\text { hydroperoxide peroxidase (PHGPx) }\end{array}$ & 6689393 \\
\hline $\begin{array}{l}1-102,103,104 ; 2-64,66,67 \\
2-62,63 ; 3-40\end{array}$ & $\begin{array}{l}\text { Ornithine carbamoyltransferase, mitochondrial } \\
\text { precursor }\end{array}$ & OTC_PIG \\
\hline $4-79$ & $\begin{array}{l}\text { Peptidyl-prolyl cis-trans isomerase A (Rotamase A, } \\
\text { Cyclophilin A) }\end{array}$ & PPIA_AOTTR \\
\hline $3-70$ & Peroxiredoxin 1 & 6754976 \\
\hline $1-9,10 ; 5-32$ & Peroxiredoxin-2 (Thioredoxin peroxidase 1) & 1717797 \\
\hline $2-25,29$ & $\begin{array}{l}\text { Peroxiredoxin-3 (Thioredoxin-dependent peroxide } \\
\text { reductase) }\end{array}$ & PRDX3_BOVIN \\
\hline $2-27$ & Peroxiredoxin-4 (thioredoxin peroxidase) & 5453549 \\
\hline $1-4$ & Peroxiredoxin-5 & 10305336 \\
\hline $2-26,33$ & $\begin{array}{l}\text { Peroxiredoxin- } 6 \text { (non-selenium glutathione } \\
\text { peroxidase) }\end{array}$ & PRDX6_PIG \\
\hline $1-70$ & Phenol sulfotransferase & 37780220 \\
\hline
\end{tabular}


Table 1 (Continued)

\begin{tabular}{|c|c|c|}
\hline Gel and spot number & Protein identification & Representative accession no. \\
\hline $1-167$ & Phenylalanine-4-hydroxylase & PH4H_HUMAN \\
\hline $\begin{array}{l}1-204,206,219 ; 2-180,181 ; 3-3 ; \\
\quad 4-2\end{array}$ & Phosphoenolpyruvate carboxykinase [GTP] & PPCKM_MOUSE \\
\hline $1-207,217,229$ & Phosphoglucomutase-1 & PGM1_HUMAN \\
\hline $1-54$ & Phosphoglycerate mutase 1 & 44890768 \\
\hline $5-55$ & Phosphomannomutase 2 & PMM2_BOVIN \\
\hline $3-27$ & phosphoserine aminotransferase isoform 1 & 17402893 \\
\hline $4-80$ & Profilin-1 & PROF1_BOVIN \\
\hline $2-35 ; 6-9$ & Prohibitin & PHB_BOVIN \\
\hline $1-180$ & Proline dipeptidase (Predicted) & 76640954 \\
\hline $2-133 ; 5-10 ; 6-20$ & $\begin{array}{l}\text { Prolyl 4-hydroxylase subunit beta (thyroid hormone } \\
\text { binding protein) }\end{array}$ & PDIA1_BOVIN \\
\hline $2-103,106$ & $\begin{array}{l}\text { Propanoyl-CoA C-acyltransferase (NLTP_RABIT) } \\
\text { BP451909 swine cDNA library, clone } \\
\text { LVRM10013E09 5' }\end{array}$ & 40441976 \\
\hline $1-263 ; 2-154,201$ & $\begin{array}{l}\text { Propionyl-CoA carboxylase alpha chain, } \\
\text { mitochondrial precursor }\end{array}$ & PCCA_MOUSE \\
\hline $1-243 ; 2-166$ & Propionyl-CoA carboxylase beta chain precursor & 47522682 \\
\hline $1-59$ & Prosomal protein $\mathrm{P} 30-33 \mathrm{~K}$ & 190447 \\
\hline $3-45$ & $\begin{array}{l}\text { Prostaglandin F synthase (aldo-keto reductase } \\
\text { family } 1 \text { member } \mathrm{C} 4 \text { ) }\end{array}$ & 61741954 \\
\hline $5-67$ & $\begin{array}{l}\text { Proteasome } 26 \mathrm{~S} \text { non-ATPase regulatory subunit S5 } \\
\text { (Predicted) }\end{array}$ & 73971550 \\
\hline $5-59$ & $\begin{array}{l}\text { Proteasome } 26 \mathrm{~S} \text { subunit ATPase } 3,(26 \mathrm{~S} \text { protease } \\
\text { regulatory subunit } 6 \mathrm{~A})\end{array}$ & PRS6A_HUMAN \\
\hline $5-50$ & $\begin{array}{l}\text { Proteasome } 26 \mathrm{~S} \text { subunit ATPase } 4 \text { ( } 26 \mathrm{~S} \text { protease } \\
\text { regulatory subunit } 6 \mathrm{~B} \text { ) }\end{array}$ & PRS6B_BOVIN \\
\hline $1-64$ & Proteasome activator 28 alpha subunit & 34978646 \\
\hline $1-67$ & Proteasome activator 28 beta subunit & 34978648 \\
\hline $1-28$ & Proteasome beta 3 subunit & 6755202 \\
\hline $5-14$ & Proteasome subunit alpha type 5 & PSA5_HUMAN \\
\hline $1-41$ & Proteasome subunit beta type 2 & PSB2_BOVIN \\
\hline $5-2$ & $\begin{array}{l}\text { Proteasome subunit beta type } 6 \text { precursor (delta } \\
\text { chain) }\end{array}$ & PSB6_HUMAN \\
\hline $1-22$ & proteasome subunit, beta type 4 & 77735487 \\
\hline $2-92 ; 6-16$ & Protein disulfide isomerase related protein 5 & 1710248 \\
\hline $1-178 ; 2-143,158,161,164$ & $\begin{array}{l}\text { Protein disulfide-isomerase A3 precursor (ERp60, } \\
58 \mathrm{kDa} \text { microsomal protein) }\end{array}$ & PDIA3_HUMAN \\
\hline $2-136$ & Protein disulfide-isomerase A4 precursor & PDIA4_HUMAN \\
\hline $3-62$ & Quinoid dihydropteridine reductase & 47523746 \\
\hline $\begin{array}{l}1-74,75,78,79,80 ; 2-39 ; 3-41 \\
\quad 6-11\end{array}$ & Regucalcin & 116175265 \\
\hline $\begin{array}{l}1-200,210,233,238,239 \\
\quad 3-9,11,13 ; 4-16\end{array}$ & $\begin{array}{l}\text { Retinal dehydrogenase } 1 \text { (ADH family } 1 \text { member } \\
\text { A1) }\end{array}$ & AL1A1_HORSE \\
\hline $2-9$ & Retinol-binding protein precursor (PRBP) & RETBP_PIG \\
\hline $1-6,13$ & Rho Family Gtp-Binding Protein Cdc 42 , chain b & 7245833 \\
\hline $5-33$ & $\begin{array}{l}\text { Rho GDP-dissociation inhibitor } 1 \text { (Rho GDI 1, } \\
\text { alpha) }\end{array}$ & GDIR_BOVIN \\
\hline $1-89,90 ; 2-57,58 ; 3-54 ; 4-44$ & Rhodanese & THTR_BOVIN \\
\hline $1-99$ & $\begin{array}{l}\text { Ribose-phosphate pyrophosphokinase II (PRS-II) } \\
\text { isoform } 3\end{array}$ & PRPS2_HUMAN \\
\hline $1-140$ & $S$-Adenosylhomocysteine hydrolase & 58801555 \\
\hline $1-183,186$ & $S$-Adenosylmethionine synthetase isoform type-1 & METK1_RAT \\
\hline $3-19$ & $\begin{array}{l}\text { SEC14-like protein } 2 \text { (Alpha-tocopherol-associated } \\
\text { protein) }\end{array}$ & S14L2_BOVIN \\
\hline $1-156,157$ & SEC14-like protein 3 (45 kDa secretory protein) & S14L3_RAT \\
\hline $1-233,235,237,238,239,248$ & Selenium binding protein 1 & SBP1_HUMAN \\
\hline $1-235,238$ & $\begin{array}{l}\text { Selenium-binding protein } 2(56 \mathrm{kDa} \\
\text { acetaminophen-binding protein) }\end{array}$ & SBP2_MOUSE \\
\hline
\end{tabular}


Table 1 (Continued)

\begin{tabular}{|c|c|c|}
\hline Gel and spot number & Protein identification & Representative accession no. \\
\hline $1-198,211,212$ & Serine hydroxymethyltransferase, cytosolic & GLYC_RABIT \\
\hline $5-47$ & $\begin{array}{l}\text { Serine/threonine-protein phosphatase } 2 \mathrm{~A} 65 \mathrm{kDa} \\
\text { regulatory subunit A alpha isoform }\end{array}$ & 2AAA_PIG \\
\hline $1-65$ & Short-chain dehydrogenase/reductase & 27807265 \\
\hline $\begin{array}{l}1-108,109,118,119 ; 2-60 \\
\quad 3-24,25,32\end{array}$ & Sorbitol dehydrogenase & DHSO_BOVIN \\
\hline $4-4,82$ & Sterol carrier protein-2 & 200942 \\
\hline $1-31$ & $\begin{array}{l}\text { Substrate protein of ATP-dependent proteinase } \\
\text { SP-22 (peroxiredoxin family) }\end{array}$ & 627764 \\
\hline $4-69$ & $\begin{array}{l}\text { Succinate dehydrogenase [ubiquinone] } \\
\text { mitochondrial precursor }\end{array}$ & DHSB_BOVIN \\
\hline $5-61 ; 6-12$ & $\begin{array}{l}\text { Succinyl-CoA ligase [GDP-forming] beta-chain, } \\
\text { mitochondrial precursor }\end{array}$ & SUCB2_PIG \\
\hline $1-3 ; 2-4$ & Superoxide dismutase $[\mathrm{Cu}-\mathrm{Zn}]$ & SODC_PIG \\
\hline $1-179$ & T-Complex protein 1 subunit alpha B (TCP-1-alpha) & TCPA2_MOUSE \\
\hline $1-235,238,239 ; 2-125$ & T-Complex protein 1 subunit beta (TCP-1-beta & TCPB_BOVIN \\
\hline $1-227$ & $\begin{array}{l}\text { T-Complex protein } 1 \text { subunit gamma } \\
\text { (TCP-1-gamma)-chaparonin }\end{array}$ & TCPG_BOVIN \\
\hline $1-229$ & T-Complex protein 1 subunit zeta (TCP-1-zeta) & TCPZ_BOVIN \\
\hline $2-90$ & $\begin{array}{l}\text { Thioredoxin domain containing } 4 \text { (endoplasmic } \\
\text { reticulum) }\end{array}$ & 78042524 \\
\hline $2-29$ & $\begin{array}{l}\text { Thioredoxin-dependent peroxide reductase } \\
\text { (Predicted) confirmed by MS/MS }\end{array}$ & 73998671 \\
\hline $4-55$ & $\begin{array}{l}\text { trans-2-Enoyl-CoA reductase, peroxisomal } \\
\text { (PECR_RAT) BP141613 swine cDNA clone } \\
\text { OVR010044A10, 5' }\end{array}$ & 40391084 \\
\hline $2-183,184,185 ; 4-1$ & Transferrin & TRFE_PIG \\
\hline $5-48,56$ & $\begin{array}{l}\text { Transitional endoplasmic reticulum ATPase (TER, } \\
15 \mathrm{~S} \mathrm{Mg}(2+) \text {-ATPase p97 subunit) }\end{array}$ & TERA_PIG \\
\hline $1-205 ; 3-3,4$ & Transketolase & TKT_BOVIN \\
\hline $5-3$ & Translationally controlled tumor protein (TCTP) & TCTP_PIG \\
\hline $1-45,49 ; 3-66$ & Triosephosphate isomerase 1 & 91214448 \\
\hline $5-7$ & Tropomyosin 3 isoform 2 isoform 3 (Predicted) & 73961067 \\
\hline $5-12$ & Tubulin alpha- 3 chain & TBA3_CRIGR \\
\hline $5-58$ & Tubulin alpha-8 chain (Alpha-tubulin 8) & TBA8_HUMAN \\
\hline $5-11,38,39 ; 6-19$ & $\begin{array}{l}\text { Tubulin beta- } 5 \text { chain (Beta-tubulin isotype I) (Class } \\
\text { I beta tubulin) }\end{array}$ & TBB5_CRIGR \\
\hline $5-6$ & $\begin{array}{l}\text { Tyrosine 3-monooxygenase/tryptophan } \\
\text { 5-monooxygenase activation protein, epsilon }\end{array}$ & 31981925 \\
\hline $4-26$ & $\begin{array}{l}\text { Ubiquinol-cytochrome-C reductase complex core } \\
\text { protein } 2\end{array}$ & UQCR2_BOVIN \\
\hline $2-95 ; 6-15$ & $\begin{array}{l}\text { Ubiquinol-cytochrome-C reductase core protein I, } \\
\text { mitochondrial precursor }\end{array}$ & UQCR1_HUMAN \\
\hline $1-200 ; 3-13,14$ & UDP-glucose pyrophosphorylase -2 & UGPA2_PIG \\
\hline $1-201,232 ; 3-8$ & UDP-glucose 6-dehydrogenase & UGDH_HUMAN \\
\hline $1-210$ & UDP-glucose pyrophosphorylase-1(UGPA1) & 731050 \\
\hline $1-33$ & $\begin{array}{l}\text { UMP-CMP kinase (Cytidylate kinase, } \\
\text { Deoxycytidylate kinase) }\end{array}$ & 2497487 \\
\hline $1-269$ & Urocanase domain containing 1 (Predicted) & 76622316 \\
\hline $2-49$ & $\begin{array}{l}\text { Voltage-dependent anion channel VDAC2 (outer } \\
\text { mitochondrial membrane) }\end{array}$ & 346412 \\
\hline $4-49,58$ & $\begin{array}{l}\text { Voltage-dependent anion-selective channel protein } 1 \\
\text { (VDAC-1) }\end{array}$ & VDAC1_PIG \\
\hline $1-226$ & WDR1 protein & 3420181 \\
\hline $4-52$ & Zeta-crystallin (Quinone oxidoreductase) & 113205780 \\
\hline $1-150 ; 5-63,64$ & $\begin{array}{l}\text { Zinc-binding alcohol dehydrogenase } \\
\text { domain-containing protein } 1\end{array}$ & ZADH1_HUMAN \\
\hline
\end{tabular}




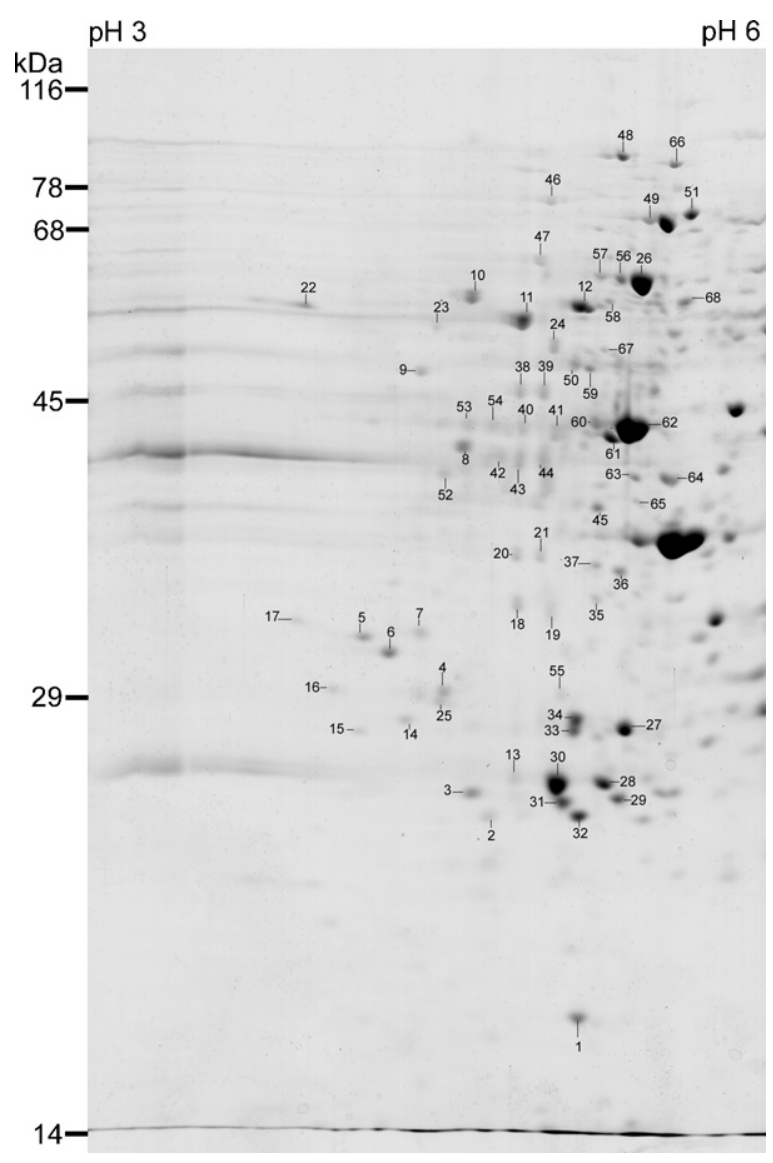

Fig. 5. Colloidal Coomassie stained 2D-PAGE of porcine hepatocyte cytosol proteins. Proteins were separated in the first dimension on a pH 3-6, $11 \mathrm{~cm}$ IPG strip. The numbered spots were prepared for MS analysis and the combined data are presented in Table 1 as gel \# 5 .

by PMF, 297 (or 78.4\%) were identified by MS/MS. Of those, only $84(28 \%)$ were positively identified as Sus scrofa proteins, again indicating a lack of overall annotated pig sequences in the public domain. For both PMF and MS/MS analyses, the remainder of the positive identifications were primarily based on bovine, human and mouse sequences. Twenty-four protein spots identified by MS/MS were characterized by "Blasting" a significant swine-EST identification against (non-pig) annotated proteins in either the NCBInr or SwissProt databases. Of those spots identified by an EST search, 11 represented unique protein identifications (3,2-trans-enoyl-CoA-isomerase-peroxisomal PECI and mitchondrial, bile acid CoA-amino acid $\mathrm{N}$ acyltransferase, dehydrogenase/reductase-SDR1, ester hydrolase, glycine- $N$-acyltransferase, hydroxysteroid dehydrogenase, ketohexokinase, nicotinate-nucleotide pyrophosphorylase, propanoyl-CoA C-acyltransferase and trans-2-enoyl-CoA reductase (see Table 1 and Sup-

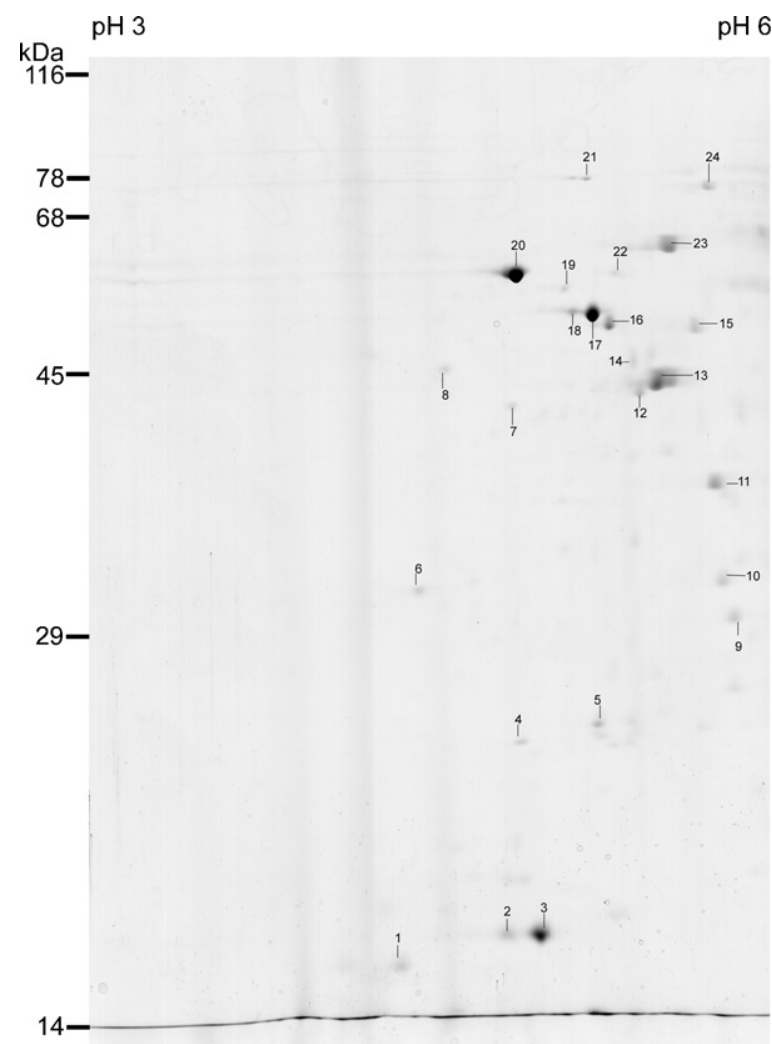

Fig. 6. Colloidal Coomassie stained 2D-PAGE of porcine hepatocyte membrane proteins. Proteins were separated in the first dimension on a pH 3-6, $11 \mathrm{~cm}$ IPG strip. The numbered spots were prepared for MS analysis and the combined data are presented in Table 1 as gel \# 6 .

plement 1). Despite the distinct paucity of available annotated pig sequence data, our observation of 282 unique proteins compares favorably to a similar study where 273 proteins were identified for rat liver where multiple narrow and broad-range 2D-PAGE were performed with very high amounts of cytosol and total protein [19]. In addition, the multiple $\mathrm{pH}$ range approach to mapping mammalian tissue proteome appears well suited by comparison to a single large gel format broadrange analysis where 111 proteins were identified from 1000 candidate spots of a human pituitary adenoma [22] or 212 proteins from human kidney glomerulus [23] using similar PMF and MS/MS identification techniques.

In the present study, we have utilized analytical quantities of protein to ensure good separation for future comparative purposes and to provide a detailed 2D map such that the vast majority of protein spots were composed of single proteins. Of the 349 proteins identified by PMF 98.3\% were single protein spots and 6 spots were determined to contain two different proteins. With the proteins identified by MS/MS, $90.2 \%$ were single pro- 
tein identifications. Most of the 29 multiple spots were identified with two proteins (23), while 1 spot (gel 1, spot 238) contained 6 unique proteins and another spot (gel 1, spot 239) contained 5 proteins. Of the unique proteins that were identified 130 were limited to the cytosol gels (1, 3 and 5) and were represented by prototypical cytoplasmic proteins such as beta actin, esterase-D, ferritin and lactate dehydrogenase. Eighty-four proteins were observed only in the membrane gels (2, 4 and 6) and these were represented primarily by mitochondrial and peroxisomal proteins including aconitase, succinate dehydrogenase, beta hydroxybutyrate dehydrogenase, ketoacyl thiolase, hydroxyacid oxidase, acylcoenzyme A synthetase. Transferrin (a soluble, secreted protein) was observed in the membrane fraction and probably reflects its association with the lysosome/endosome compartment. The remaining proteins (68) were distributed among all gels and probably represent incomplete initial fractionation and the use of frozen cells as starting material. In addition many gene products may indeed be present in multiple locations within the cell.

Proteins observed were widely distributed among the known functional categories associated with liver metabolism (Fig. 7). Protein metabolic pathways including synthesis, degradation, folding and post-translational modification accounted for the highest percentage of observed proteins $(20.2 \%)$, followed by lipid metabolism including fatty acid synthesis and oxidation and cholesterol, steroid and bile acid metabolism (18.8\%). Cellular energetics, including electron transport, glycolysis, gluconeogeneis, carbohydrate metabolism, and TCA cycle were associated with $14.9 \%$ of identified proteins, while amino acid metabolism represented $13.8 \%$ and detoxification activities including antioxidant proteins represented $9.2 \%$. As expected, there was a distinct lack of microsomal proteins such as the drug/steroid metabolizing major cytochrome $\mathrm{P}-450$ proteins, in both the membrane and cytosol fractions [24]. Accordingly, proteomic analysis of prepared porcine hepatocyte microsomes, for the specific identification of cytochrome P450 content and activity are currently under investigation in our laboratory.

In conclusion, we have presented the first comprehensive proteomic analysis of porcine hepatic cells (by 2D-PAGE/MS analysis) and in particular, these are the only data that have been assembled identifying major proteins in freshly isolated pig hepatocytes. While porcine hepatic tissue has been previously separated by 2D-PAGE $[25,26]$ to date, only limited protein identification or analyses have been reported. The data presented here will serve as a basis to compare more-refined subcellular fractionation techniques and will allow future comparison of changes associated with cell culture or in vivo endocrine and nutritional interactions.

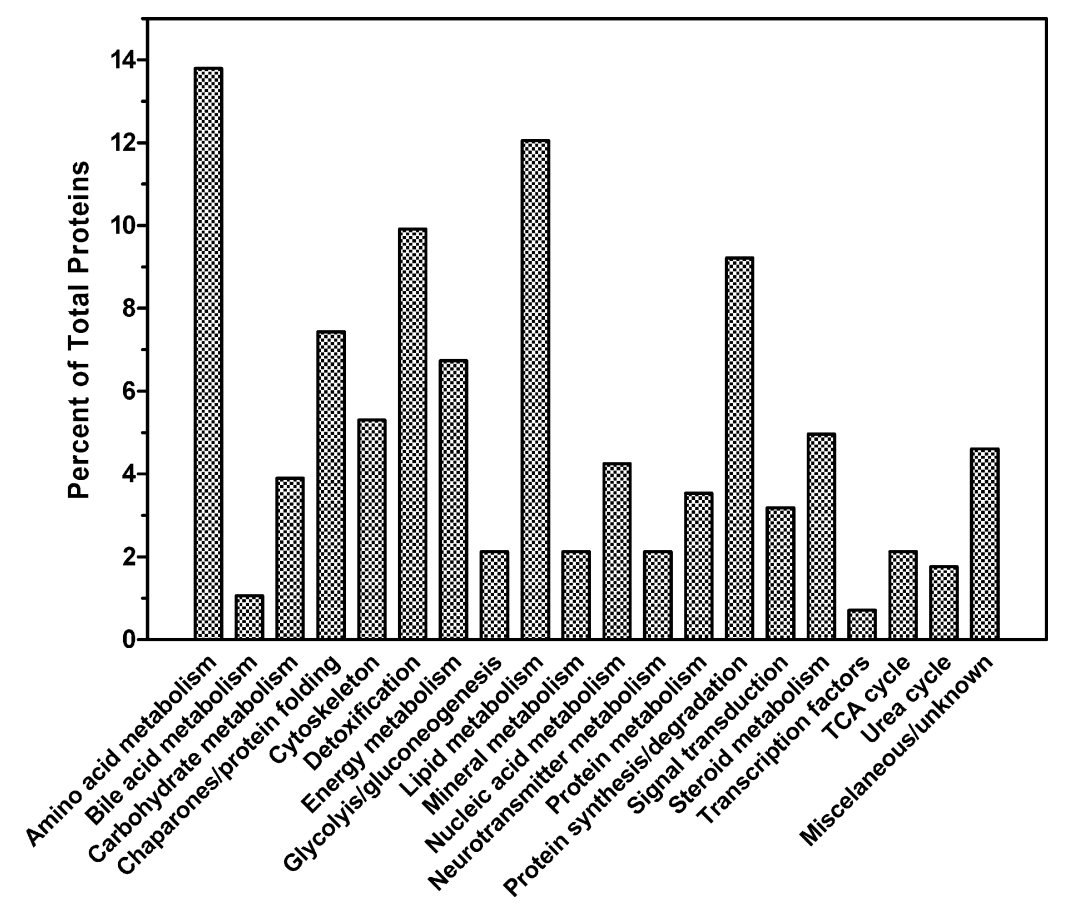

Fig. 7. Classification of uniquely identified proteins from porcine hepatocytes. Main biological functions were grouped according to public database classification (http://www.geneontology.org and http://us.expasy.org/sprot). 


\section{Acknowledgements}

Dr. J.P. McMurtry is thanked for critical review of the manuscript and Janile Tapscott, James Woods and Jim Piatt are thanked for assistance in maintaining and handling experimental animals.

\section{Appendix A. Supplementary data}

Supplementary data associated with this article can be found, in the online version, at doi:10.1016/j. domaniend.2007.12.004.

\section{References}

[1] Odle J. New insights into the utilization of medium-chain triglycerides by the neonate: observations from a piglet model. J Nutr 1997;127:1061-7.

[2] Raman P, Donkin SS, Spurlock ME. Regulation of hepatic glucose metabolism by leptin in pig and rat primary hepatocyte cultures. Am J Physiol Regul Integr Comp Physiol 2004;286: R206-16.

[3] Terner MA, Gilmore J, Lou Y, Squires EJ. The role of CYP2A and CYP2E1 in the metabolism of 3-methylindole in primary cultured porcine hepatocytes. Drug Metab Dispos 2006;34:848-54.

[4] Caperna TJ, Shannon AE, Richards MP, Garrett WM, Talbot NC. Identiofication and characterization of aquaporin-9 (AQP9) in porcine hepatic tissue and hepatocytes in monolayer culture. Domest Anim Endocrinol 2007;32:273-86.

[5] O'Grady J. Personal view: current role of artificial liver support devices. Aliment Pharmacol Ther 2006;23:1549-57.

[6] Deglmann CJ, Metzger R, Stickel M, Hoerrlein S, Schildberg FW, Koebe HG. A new bioassay including a small scale bioreactor for hepato-mediated toxicity testing in a target cell line. Int J Artif Organs 2002;25:975-84.

[7] Witzmann FA, Clack JW, Geiss K, Hussain S, Juhl MJ, Rice CM, et al. Proteomic evaluation of cell preparation methods in primary hepatocyte cell culture. Electrophoresis 2002;23:2223-32.

[8] Fernández-Fígares I, Shannon AE, Wray-Cahen D, Caperna TJ. The role of insulin, glucagon, dexamethasone, and leptin in the regulation of ketogenesis and glycogen storage in primary cultures of porcine hepatocytes prepared from $60 \mathrm{~kg}$ pigs. Domest Anim Endocrinol 2004;27:125-40.

[9] Caperna TJ, Shannon AE, Poch SM, Garrett WM, Richards MP. Hormonal regulation of leptin receptor expression in primary cultures of porcine hepatocytes. Domest Anim Endocrinol 2005;29:582-92.

[10] Talbot NC, Caperna TJ, Wells KD. The PICM-19 cell line as an in vitro model of liver bile ductules: effects of cAMP inducers, biopeptides and pH. Cells Tissues Org 2002;171:99-116.

[11] Caperna TJ, Failla ML, Kornegay ET, Richards MP, Steele NC. Isolation and culture of parenchymal and nonparenchymal cells from neonatal swine liver. J Anim Sci 1985;61:1576-86.
[12] Ruiz-Cortés ZT, Men T, Palin M-F, Downey BR, Lacroix DA, Murphy BD. Porcine leptin receptor: molecular structure and expression in the ovary. Mol Reprod Dev 2000;56: 465-74.

[13] Nerurkar LS, Marino PA, Adams DO. Quantification of selected intracellular and secreted hydrolases of macrophages. In: Herscowitz HB, Holden HT, Bellanti JA, Ghaffer A, editors. Manual of macrophage methodology. Marcel Dekker, Inc.; 1981. p. 229-47.

[14] Hoving S, Gerrits B, Voshol H, Müller D, Roberts RC, van Ostrum J. Preparative two-dimensional gel electrophoresis at alkaline $\mathrm{pH}$ using narrow range immobilized $\mathrm{pH}$ gradients. Proteomics 2002;2:127-34.

[15] Laemmli UK. Cleavage of structural proteins during the assembly of the head of bacteriophage T4. Nature 1970;227:680-5.

[16] Werner WE. Run parameters affecting protein patterns from second dimension electrophoresis gels. Anal Biochem 2003;317:280-3.

[17] Newsholme SJ, Maleeff BF, Steiner S, Anderson NL, Schwartz LW. Two-dimensional electrophoresis of liver proteins: characterization of a drug-induced hepatomegaly in rats. Electrophoresis 2000;21:2122-8.

[18] Perkins DN, Pappin DJ, Creasy DM, Cottrell JS. Probabilitybased protein identification by searching sequence databases using mass spectrometry data. Electrophoresis 1999;20:3551-67.

[19] Fountoulakis M, Suter L. Proteomic analysis of the rat liver. J Chromatogr B 2002;782:197-218.

[20] Leenders F, Husen B, Thole HH, Adamski J. The sequence of porcine $80 \mathrm{kDa} 17$ beta-estradiol dehydrogenase reveals similarities to the short chain alcohol dehydrogenase family, to actin binding motifs and to sterol carrier protein 2. Mol Cell Endocrinol 1994;104:127-31.

[21] Struck J, Ühlein M, Morgenthaler NG, Fürst W, Höflich C, Bahrami S, et al. Release of mitochondrial enzyme carbamoyl phosphate synthase under septic conditions. Shock 2005;6: 533-8.

[22] Zhan X, Desiderio DM. A reference map of a human pituitary adenoma proteome. Proteomics 2003;3:699-713.

[23] Yoshida Y, Miyazaki K, Kamiie J, Sato M, Okuizumi S, Kenmochi A, et al. Two-dimensional electrophoretic profiling of normal human kidney glomerulus proteome and construction of an extensible markup language (XML)-based database. Proteomics 2005;5:1083-96.

[24] Galeva N, Altermann M. Comparison of one-dimensional and two-dimensional gel electrophoresis as a separation tool for proteomic analysis of rat liver microsomes: cytochrome P450 and other membrane proteins. Proteomics 2002;2:713-22.

[25] Junghans P, Kaehne T, Beyer M, Metges CC, Schwerin M. Dietary protein-related changes in hepatic transcription correspond to modifications in hepatic protein expression in growing pigs. $\mathrm{J}$ Nutr 2004;134:43-7.

[26] Poznanovic S, Schwall G, Zengerling H, Cahill MA. Isoelectric focusing in serial immobilized $\mathrm{pH}$ gradient gels to improve protein separation in proteomic analysis. Electrophoresis 2005;26:3185-90. 